\title{
ATP-Binding Cassette Sub-Family G Member 1
}

National Cancer Institute

\section{Source}

National Cancer Institute. ATP-Binding Cassette Sub-Family G Member 1. NCI Thesaurus.

Code C113601.

AT P-binding cassette sub-family G member 1 ( $678 \mathrm{aa}, \sim 76 \mathrm{kDa}$ ) is encoded by the human ABCG1 gene. This protein is involved in the transport of cholesterol and phospholipids. 